\title{
Glutamate NMDA receptor modulators for the treatment of depression: trials and tribulations
}

\author{
James W. Murrough
}

Received: 29 January 2015 / Accepted: 19 February 2015 / Published online: 11 March 2015

(C) Springer-Verlag Berlin Heidelberg 2015

Several decades of research have provided evidence for disturbances within the glutamate system in patients with depressive disorders and have pointed towards the glutamate system as a target for treatment development for mood disorders (Sanacora et al. 2008; Skolnick et al. 2009). In particular, clinical studies showing a rapid antidepressant effect of the glutamate N-methyl-D-aspartate (NMDA) receptor (NMDAR) antagonist ketamine provide a critical proof of principle for targeting the NMDAR as a novel treatment approach for refractory forms of unipolar and bipolar depression (Murrough and Charney 2010). Fifteen years have passed since the first clinical study of ketamine in depression was published (Berman et al. 2000). To date, no agents targeting the NMDAR or other components of the glutamate system have gained regulatory approval for the treatment of depression. During the past 15 years, what has the field learned?

The original publication by Berman et al. reported the rapid antidepressant effect of a single intravenous infusion of ketamine $(0.5 \mathrm{mg} / \mathrm{kg})$ compared to saline using a randomized, within-subject crossover design (Berman et al. 2000). This

J. W. Murrough $(\bowtie)$

Mood and Anxiety Disorders Program, Department of Psychiatry,

Icahn School of Medicine at Mount Sinai, One Gustave L. Levy

Place, Box 1230, New York, NY 10029, USA

e-mail: james.murrough@mssm.edu

J. W. Murrough

Fishberg Department of Neuroscience, Icahn School of Medicine at Mount Sinai, New York, NY, USA

J. W. Murrough

Friedman Brain Institute, Icahn School of Medicine at Mount Sinai, New York, NY, USA finding was followed by a milestone publication by Zarate et al. in 2006 demonstrating a rapid antidepressant effect of ketamine specifically in patients with treatment-resistant depression (TRD) in a larger sample (Zarate et al. 2006). This group went on to demonstrate the rapid antidepressant effect of ketamine in patients with bipolar depression (Diazgranados et al. 2010; Zarate et al. 2012). Our group built on these findings, conducting the largest study of single-administration ketamine in TRD to date, involving 73 patients randomized across two sites in a parallel-arm design (Murrough et al. 2013a). This study featured the anesthetic benzodiazepine agent midazolam as a "psychoactive control" condition, designed to mitigate the threat of un-blinding related to the acute psychoactive effects of ketamine. Compared to midazolam, ketamine was associated with a higher rate of antidepressant response at $24 \mathrm{~h}$ post-treatment [64 and $28 \%$, respectively; odds ratio (OR) 2.18]. Separately, we demonstrated the feasibility and preliminary efficacy of repeated administrations of ketamine in patients with TRD, administering up to six doses over 2 weeks (aan het Rot et al. 2010; Murrough et al. 2013b). New data on the effects of ketamine administered in an intranasal fashion in TRD is also promising (Lapidus et al. 2014). A recent meta-analysis included seven randomized controlled trials (RCTs) of ketamine in mood disorders, involving a total of 183 subjects (McGirr et al. 2014). Relative to the comparator, a single administration of ketamine was associated with higher odds of antidepressant response at 24 h, 3 days, and 7 days post-treatment [OR 9.1, 6.8, and 4.9, respectively; number needed to treat (NNT) ranged from 3 to 4]. A second meta-analysis published recently in Psychopharmacology included nine controlled studies of ketamine in mood disorders and likewise found that depression scores were significantly decreased in the ketamine groups compared to those in the 
control groups (standardized mean difference of $0.99,95 \% \mathrm{CI}$ 1.23-0.77) (Fond et al. 2014).

Given the accumulated data, may we conclude that the therapeutic benefit of ketamine for depression has been established? The question is more complex than it may first appear. In particular, it is instructive to draw a distinction between the question of pure efficacy demonstrated in a controlled environment and the larger questions of effectiveness in real world settings and the favorability (or lack thereof) of the treatment risk-to-benefit ratio. The answer to the first question is of critical importance to the science of mood disorders and is a necessary prerequisite to begin to address the latter questions. Taking the first question first, the accumulated data does appear to confirm the rapid antidepressant efficacy of ketamine. What are the implications of this discovery? Foremost, this fact provides the most robust evidence available linking the NMDAR, and the glutamate system more broadly, to the pathophysiology of depression. This realization should prompt substantial research investment aimed at characterizing the role of the NMDAR in depression. The discovery also provides the key rationale to pursue the NMDAR and its related molecular machinery as targets for novel treatment development efforts. While government and non-profit organizations are focused on the former, the industry is appropriately focused on the latter.

One question that has arisen regarding the antidepressant mechanism of action of ketamine is as follows: To what extent is the efficacy of ketamine dependent on the NMDAR? This is an empirical question that no doubt requires further study. A preponderance of data, however, shows that the physiological properties of ketamine are mediated primarily by its function as a noncompetitive, high-affinity, NMDAR antagonist (Hirota and Lambert 1996; Potter and Choudhury 2014). At binding affinities much lower than that of the NMDAR, ketamine interacts with opioid and cholinergic receptors, among others (Hirota and Lambert 1996). Ketamine does have abuse liability, and its actions at opioid receptors in particular merit additional consideration. Although complex, ketamine appears to function as an antagonist at mu receptors (rather than an agonist, such as morphine) and an agonist at kappa receptors (Smith et al. 1985; Hustveit et al. 1995). Of note, the sedative effects of ketamine in humans are not reversed by naloxone (Mikkelsen et al. 1999); furthermore, naltrexone potentiates (rather than inhibits) the perceptual effects of ketamine in humans (Krystal et al. 2006). The available evidence is consistent with the hypothesis that NMDAR antagonism, rather effects at other receptors, is the key to ketamine's antidepressant mechanism of action.

Returning to questions of effectiveness and safety, we are on less sure-footed ground. The total number of subjects studied in RCTs of ketamine in depression is less than 200 and no studies have examined the effects of ketamine over a longer time interval than a few weeks (Wan et al. 2014). Importantly, there is no safety or efficacy data concerning chronic ketamine treatment for depression. This paucity of longer-term data dictates first that prescribing clinicians must proceed with great caution and second that larger-scale studies of ketamine are needed straightaway in order to inform the risk-to-benefits analyses that are critical to patients, providers and regulators. The eagerness with which some patients and providers have embraced ketamine for the treatment of severe and refractory depression is a testament to the urgency of the need.

Following on the heels of ketamine, several other NMDAR modulators are being investigated as candidate antidepressant agents (Lapidus et al. 2013; Sanacora and Schatzberg 2015). Despite some success, several compounds have stalled during the drug development process. The failure of the low-affinity NMDAR antagonist memantine to separate from placebo in TRD was an early disappointment. Another NMDA receptor antagonist, lanicemine, has yielded mixed results and its continued development for depression is uncertain (Sanacora and Schatzberg 2015). Agents selective for the NR2B subunit of the NMDAR have shown promise in clinical trials, although there have been setbacks as well. The glycine site partial agonist D-cycloserine (DCS) demonstrated antidepressant efficacy in TRD when administered at high doses (at high doses, DCS is believed to function as an NMDAR antagonist) (Heresco-Levy et al. 2013). Dextromethorphan is an antitussive NMDAR antagonist that is beginning to be examined for potential therapeutic effects in mood disorders (Chen et al. 2014; Kelly and Lieberman 2014). A particular bright spot on the horizon may be a pair of NMDAR modulators-GLYX-13 and NRX-1074 - which are purported to show antidepressant efficacy in phase II studies, although published data is not yet available. Clearly, the field has learned a considerable amount of information concerning NMDARs as treatment targets in depression. Will we see NMDAR modulators come to market as approved therapies for depression? Will we wait another 15 years for a breakthrough in depression treatment? Will we wait longer?

Conflict of interest In the past 3 years, Dr. Murrough has served on advisory boards for Janssen Research and Development and Genentech, has provided consultation services for ProPhase, LLC, and Impel Neuropharma, and has received research support from Janssen and Avanir Pharmaceuticals; he is named on a patent pending for neuropeptide $\mathrm{Y}$ as a treatment for mood and anxiety disorders; he is named on a patent pending for lithium as a method to maintain the antidepressant response to ketamine. Dr. Dennis Charney (Dean of Icahn School of Medicine at Mount Sinai) and Icahn School of Medicine at Mount Sinai have been named on a use patent on ketamine for the treatment of depression. The Icahn School of Medicine has entered into a licensing agreement for the use of ketamine as therapy for treatment-resistant depression. Dr. Charney and Icahn School of Medicine at Mount Sinai could potentially benefit if ketamine were to gain approval for the treatment of depression. 
Funding Dr. Murrough is supported by NIH grant K23MH094707. The content is solely the responsibility of the author and does not necessarily represent the official views of the NIH

\section{References}

aan het Rot M, Collins KA, Murrough JW, Perez AM, Reich DL, Charney DS, Mathew SJ (2010) Safety and efficacy of repeateddose intravenous ketamine for treatment-resistant depression. Biol Psychiatry 67:139-145. doi:10.1016/j.biopsych.2009.08.038

Berman RM, Cappiello A, Anand A, Oren DA, Heninger GR, Charney DS, Krystal JH (2000) Antidepressant effects of ketamine in depressed patients. Biol Psychiatry 47:351-354

Chen SL, Lee SY, Chang YH, Chen PS, Lee IH, Wang TY, Chen KC, Yang YK, Hong JS, Lu RB (2014) Therapeutic effects of add-on low-dose dextromethorphan plus valproic acid in bipolar disorder. Eur Neuropsychopharmacol 24:1753-1759. doi:10.1016/j. euroneuro.2014.09.001

Diazgranados N, Ibrahim L, Brutsche NE, Newberg A, Kronstein P, Khalife S, Kammerer WA, Quezado Z, Luckenbaugh DA, Salvadore G, Machado-Vieira R, Manji HK, Zarate CA Jr (2010) A randomized add-on trial of an N-methyl-D-aspartate antagonist in treatment-resistant bipolar depression. Arch Gen Psychiatry 67: 793-802. doi:10.1001/archgenpsychiatry.2010.90

Fond G, Loundou A, Rabu C, Macgregor A, Lancon C, Brittner M, Micoulaud-Franchi JA, Richieri R, Courtet P, Abbar M, Roger M, Leboyer M, Boyer L (2014) Ketamine administration in depressive disorders: a systematic review and meta-analysis. Psychopharmacology (Berl) 231(18):3663-3676. doi:10.1007/ s00213-014-3664-5

Heresco-Levy U, Gelfin G, Bloch B, Levin R, Edelman S, Javitt DC, Kremer I (2013) A randomized add-on trial of high-dose D-cycloserine for treatment-resistant depression. Int J Neuropsychopharmacol 16:501-506. doi:10.1017/S1461145712000910

Hirota K, Lambert DG (1996) Ketamine: its mechanism(s) of action and unusual clinical uses. Br J Anaesth 77:441-444

Hustveit O, Maurset A, Oye I (1995) Interaction of the chiral forms of ketamine with opioid, phencyclidine, sigma and muscarinic receptors. Pharmacol Toxicol 77:355-359

Kelly TF, Lieberman DZ (2014) The utility of the combination of dextromethorphan and quinidine in the treatment of bipolar II and bipolar NOS. J Affect Disord 167:333-335. doi:10.1016/j.jad.2014. 05.050

Krystal JH, Madonick S, Perry E, Gueorguieva R, Brush L, Wray Y, Belger A, D'Souza DC (2006) Potentiation of low dose ketamine effects by naltrexone: potential implications for the pharmacotherapy of alcoholism. Neuropsychopharmacology 31:1793-1800

Lapidus KA, Soleimani L, Murrough JW (2013) Novel glutamatergic drugs for the treatment of mood disorders. Neuropsychiatr Dis Treat 9:1101-1112. doi:10.2147/NDT.S36689

Lapidus KA, Levitch CF, Perez AM, Brallier JW, Parides MK, Soleimani L, Feder A, Iosifescu DV, Charney DS, Murrough JW (2014) A randomized controlled trial of intranasal ketamine in major depressive disorder. Biol Psychiatry 76:970-976. doi:10.1016/j. biopsych.2014.03.026

McGirr A, Berlim MT, Bond DJ, Fleck MP, Yatham LN, Lam RW (2014) A systematic review and meta-analysis of randomized, doubleblind, placebo-controlled trials of ketamine in the rapid treatment of major depressive episodes. Psychol Med 45(4):693-704

Mikkelsen S, Ilkjaer S, Brennum J, Borgbjerg FM, Dahl JB (1999) The effect of naloxone on ketamine-induced effects on hyperalgesia and ketamine-induced side effects in humans. Anesthesiology 90:1539 1545

Murrough JW, Charney DS (2010) Cracking the moody brain: lifting the mood with ketamine. Nat Med 16:1384-1385. doi:10.1038/ nm1210-1384

Murrough JW, Iosifescu DV, Chang LC, Al Jurdi RK, Green CE, Perez AM, Iqbal S, Pillemer S, Foulkes A, Shah A, Charney DS, Mathew SJ (2013a) Antidepressant efficacy of ketamine in treatmentresistant major depression: a two-site randomized controlled trial. Am J Psychiatry 170:1134-1142. doi:10.1176/appi.ajp.2013. 13030392

Murrough JW, Perez AM, Pillemer S, Stern J, Parides MK, aan het Rot M, Collins KA, Mathew SJ, Charney DS, Iosifescu DV (2013b) Rapid and longer-term antidepressant effects of repeated ketamine infusions in treatment-resistant major depression. Biol Psychiatry 74:250-256. doi:10.1016/j.biopsych.2012.06.022

Potter DE, Choudhury M (2014) Ketamine: repurposing and redefining a multifaceted drug. Drug Discov Today 19:1848-1854. doi:10.1016/ j.drudis.2014.08.017

Sanacora G, Schatzberg AF (2015) Ketamine: promising path or false prophecy in the development of novel therapeutics for mood disorders? Neuropsychopharmacology 40:259-267. doi:10.1038/npp. 2014.261

Sanacora G, Zarate CA, Krystal JH, Manji HK (2008) Targeting the glutamatergic system to develop novel, improved therapeutics for mood disorders. Nat Rev Drug Discov 7:426-437. doi:10.1038/ $\operatorname{nrd} 2462$

Skolnick P, Popik P, Trullas R (2009) Glutamate-based antidepressants: 20 years on. Trends Pharmacol Sci 30:563-569. doi:10.1016/j.tips. 2009.09.002

Smith DJ, Perrotti JM, Mansell AL, Monroe PJ (1985) Ketamine analgesia is not related to an opiate action in the periaqueductal gray region of the rat brain. Pain 21:253-265

Wan LB, Levitch CF, Perez AM, Brallier JW, Iosifescu DV, Chang LC, Foulkes A, Mathew SJ, Charney DS, Murrough JW (2014) Ketamine safety and tolerability in clinical trials for treatmentresistant depression. J Clin Psychiatry. doi:10.4088/JCP.13m08852

Zarate CA Jr, Singh JB, Carlson PJ, Brutsche NE, Ameli R, Luckenbaugh DA, Charney DS, Manji HK (2006) A randomized trial of an $\mathrm{N}$-methyl-D-aspartate antagonist in treatment-resistant major depression. Arch Gen Psychiatry 63:856-864. doi:10.1001/ archpsyc.63.8.856

Zarate CA Jr, Brutsche NE, Ibrahim L, Franco-Chaves J, Diazgranados N, Cravchik A, Selter J, Marquardt CA, Liberty V, Luckenbaugh DA (2012) Replication of ketamine's antidepressant efficacy in bipolar depression: a randomized controlled add-on trial. Biol Psychiatry 71:939-946. doi:10.1016/j.biopsych.2011.12.010 